\title{
Analysis of Factors Affecting the Allocative Efficiency of Maize Production: In Case of Nunu Kumba Woreda, East Wollega Zone
}

\author{
Shuramu Tasgara
}

\begin{abstract}
Allocative efficiency is one of the most important measures of firm profitability. Hence, this study was aimed to examine the efficient utilization of existing resources and identify the effect of socio-economic and institutional factors on the allocative efficiency of maize production. The multi-stage sampling procedure was applied to the population of maize farmers from the area under study and 330 respondents were proportionally selected from four kebeles of the study area. A Stochastic production frontier model was used to estimate economic and technical efficiency score which used to drive allocative efficiency score, while Tobit model was used to identify factors affecting allocative efficiency score. The result of the study shows that allocative efficiency score was 79.49 with a minimum of $47.23 \%$, and a maximum of 94.4 . The Tobit model estimation result revealed that Allocative efficiency was positively and significantly affected by education, farm size, livestock holding, and market distance, while negatively and significantly affected by sex, age, family size, off-farm income, and credit utilization. Accordingly, the study recommended the need to supply enough amounts of improved seed and fertilizer on time to increase maize productivity. It also suggested the need for policy to encourage farmers' education, easily available and affordable credit services on time, increase the provision of extension service as well as give training for farmers on correct input application and improved farm technologies to improve the production efficiency of maize farms.
\end{abstract}

Keywords: Allocative Efficiency, SFA, Tobit, Cobb-Douglas

DOI: $10.7176 / \mathrm{JNSR} / 9-23-05$

Publication date: December $31^{\text {st }} 2019$

\section{Introduction}

Agriculture is crucial in achieving global poverty reduction targets and especially in the lowest income countries, still it is the single most important productive sector. In most poor countries, especially in sub-Saharan Africa, large majorities of the population live in rural areas and deserve their livelihoods primarily on agriculture (Gollin, 2009).

The Majority of a poor and food insecure in Africa live in the rural region and most of them depend on farming in favor of their livelihoods. To enhance broad-based poverty reduction and to ensure food security in Africa, great investment must be made on smallholder farmers. (Garvelink et al., 2012).

Agriculture in Ethiopia is the base of the country's economy, accounting for half of GDP, 83.9\% of exports, and $80 \%$ of total employment. Agriculture accounts for 46.3 percent of the nation's GDP, 83.9 percent of exports, and $80 \%$ of the labor force. Agriculture is the source of many other economic activities, including marketing, processing, and export of agricultural products. Production is highly subsistence in nature and most of the commodity exports are provided by smallholder farmer. The basic commodities are, coffee, pulses (e.g., beans), oilseeds, cereals, potatoes, sugarcane, and vegetables. Exports are almost completely agricultural commodities, and coffee is the largest foreign exchange earner. Ethiopia is also Africa's second biggest maize producer (NSO, 2014). At the recent time, as a sub-Saharan country, Ethiopia has the fifth largest area devoted to maize, but is second, only to South Africa, in yield and third, after South Africa and Nigeria, in production. (Abate et al., 2015).

The sufficient consumption of cereals is central to the well-being of almost all Ethiopian households (Minten, 2012). Among cereal crops produced in Ethiopia, maize is the second most widely cultivated crop next to teff and is grown under diverse agro-ecologies and socioeconomic conditions typically under rain-fed production. In Ethiopia, more than 9 million households grow maize more than for any other crop (Abate et al., 2015). After maize was initiated in the continent around the late 17th century, and it was mainly grown as a subsistence crop in the mid-latitudes (1500-2000 m above sea level) in southern, south-central, and south-western parts of the country (Huffnagel, 1961). Around 88\% of maize produced in Ethiopia is consumed as food,Very little maize is currently used as feed, but this too is changing in order to support a rapidly growing urbanization and poultry industry (Abate et al., 2015).

\section{Statement of the Problem}

The agricultural sector in Ethiopia plays essential roles in economic growth, poverty mitigation, employment creation, foreign exchange earnings and food security. During the past years, in spite of its huge contribution, its significance is limited because of numerous factors and hence it is becoming increasingly difficult to meet the food requirements of the growing population (Jon, 2007). In general, the low productivity of the sector, specifically cereal production over the past years brings low performance of the sector. This low productivity, in turn, increases 
poverty and shortage of food in rural poor farm households of the country (Alemayehu et al., 2012).

Likewise, Ethiopia has been well known for its agricultural development challenge given its large and rapidly growing population and limited and deteriorated land resource. Particularly in the area where the majority of population lives and largely agricultural production occurs, these two factors jointly caused extreme land shortages in the highland of Ethiopia. Population pressure has led to extended cultivation into forest areas. This creates a serious impact on the environment, which in turn leads rainfall fluctuation and made agricultural production very susceptible to weather shock (Xinshen et al., 2010).

According to CSA (2014) and MoA (2014) stated that average maize productivity of Ethiopia at the national level (32.54 quintals per ha) is better than the average national productivity of numerous African countries. Nevertheless, it is still low compared to that of the world average maize productivity (50 quintals per ha).

The previous studies conducted on maize production in Ethiopia have mainly been focused on the effect of socio-economic factors on allocative efficiency, while none has been done on the optimal utilization of factors of maize production, except Philipos (2014). As a result, this study focused on both the use of available resources and socio-economic factors affecting allocative efficiency of maize production. Therefore, the objective of this study was to examine the efficient utilization of existing resources and identify the effect of socio-economic and institutional factors on allocative efficiency of maize production.

\section{Review of Related literature}

Production the theory states that under competitive conditions, the firm is said to be allocative efficient if it equates the marginal returns of factor inputs to the market price of the input (Fan, 1999). Allocative efficiency is also defined as measures of the distance between the farm and the point of maximum profitability, given market prices of inputs and outputs. In other words, the allocative efficiency shows whether the use of different proportions of production factors guarantee the attainment of maximum production with a particular market price (Forsund et al., 1980).

Allocative efficiency indicating the ability to optimize the use of inputs in various proportions giving their respective prices. As the ability of a maize farmer to choose and employ the inputs in maize production to that level where their marginal returns equal their factor prices (Tijani, 2006). This theory is related to the effect of socio-economic and institutional factors on allocative efficiency.

Ugwumba (2010) investigated the allocative efficiency of 'egusi' melon production inputs in Imo state of Nigeria. The result showed that household size, cost of inputs and farm size as significant determinants of production output. Production output was also positively influenced by the land, labor (family and hired), and fertilizer, capital and seed inputs. More so, computed allocative efficiency values showed that land (1.14), fertilizer (17.44) and seed (1.76) inputs were underutilized while family labor (0.64), hired labour (0.08) and capital $(0.83)$ inputs were over utilized.

Inoni (2007) carried out the study to examine efficient resource utilization in pond fish production in Delta State, Nigeria. The estimated allocative efficiency of production resources employed was 3.22, $0.0025,0.00064$, -0.00017 , and 0.00025 respectively for pond size, feed resources, fingerlings, labor, and fixed costs. With exception of pond size which was under-utilized, all inputs used in fish farming were said to be over-utilized implying sub-optimal resource allocation in fish production. Based on results, fish farmers in Delta state of Nigeria needed to reduce on the use of over-utilized resources to achieve optimal resource allocation and this would raise the productivity of resources, increase output and hence increase revenues and net returns.

Okoye by using stochastic frontier Trans log cost and production functions measure the level of allocative efficiency and it's determinants in smallholder cocoyam production in Nigeria. The result of the analysis Indicated that individual farm level allocative efficiency was about $65 \%$. The result indicated that Farm size, Age and education negatively and significantly related to allocative efficiency. Fertilizer use, credit access and farm experience was significant and directly related to allocative efficiency (Okoye et al., 2006).

Chukwuji et al. (2006) conducted a quantitative study to determine the allocative efficiency of broiler production in Delta state of Nigeria. Results from this study estimated allocative efficiency for stock size, feed expenses, variable expenses and fixed capital inputs as $24.9,24.8,-4.6$ and 11.9 respectively. In accordance to these results, farmers were said to be allocative efficient and needed to increase the quantity of the inputs to enable them to maximize profits since the marginal value product was greater than marginal costs or unit price of inputs.

Bello (2018) analyzed the allocative efficiency of Layer and Broile production Sokoto state, Nigeria. The mean of the best 10 and the least 10 farmers were 0.98 and 0.57 , respectively. According to the result if the average farmer in the sample wants to achieve the optimum allocative efficiency of its counterpart, he/she would require $8 \%$ cost saving [i.e., 1-(0.91/0.99)*100]. Similarly, the least allocatively efficient farmers will need a cost saving of about $42 \%$ [i.e., 1- $(0.57 / 0.99) * 100$ ]. The results more portrayed that around $84 \%$ of layer farmers achieved above $80 \%$ allocative efficiency and only about $16 \%$ attained AE between $25-80 \%$. For broiler farmers, only about $46 \%$ achieved allocative efficiency above $80 \%$ and about $54 \%$ achieved AE between $25-80 \%$. 


\section{Methodology of the study}

\subsection{Description of the study area}

The study was carried out in Nunu Kumba woreda of East wollega zone of Oromia regional state. Nunu Kumba is one of 180 woredas in the Oromia Region of Ethiopia, and Located at 232km, west of Addis Ababa. Part of the East wollega Zone, Nunu Kumba is bordered on the southwest by the Didessa River, which separates it from the Ilubabor Zone, on the northwest by Jimma Arjo, on the north by Guto Wayu, on the northeast by Wama Bonaya, and on the southeast by Wama which separates it from the Jimma Zone. The administrative center of this woreda is Nunu.

This woreda was selected by the Ministry of Agriculture and Rural Development in 2004 as one of several areas for voluntary resettlement for farmers from overpopulated areas in the East Wollega Zone. Together with Amuru Jarte, Bila Seyo, Gida Kiremu, Ibantu, Jimma Arjo and Limmu, Nunu Kumba became the new home for a total of 22,462 heads of households and 112,310 total family members (Resettlement, 2004).

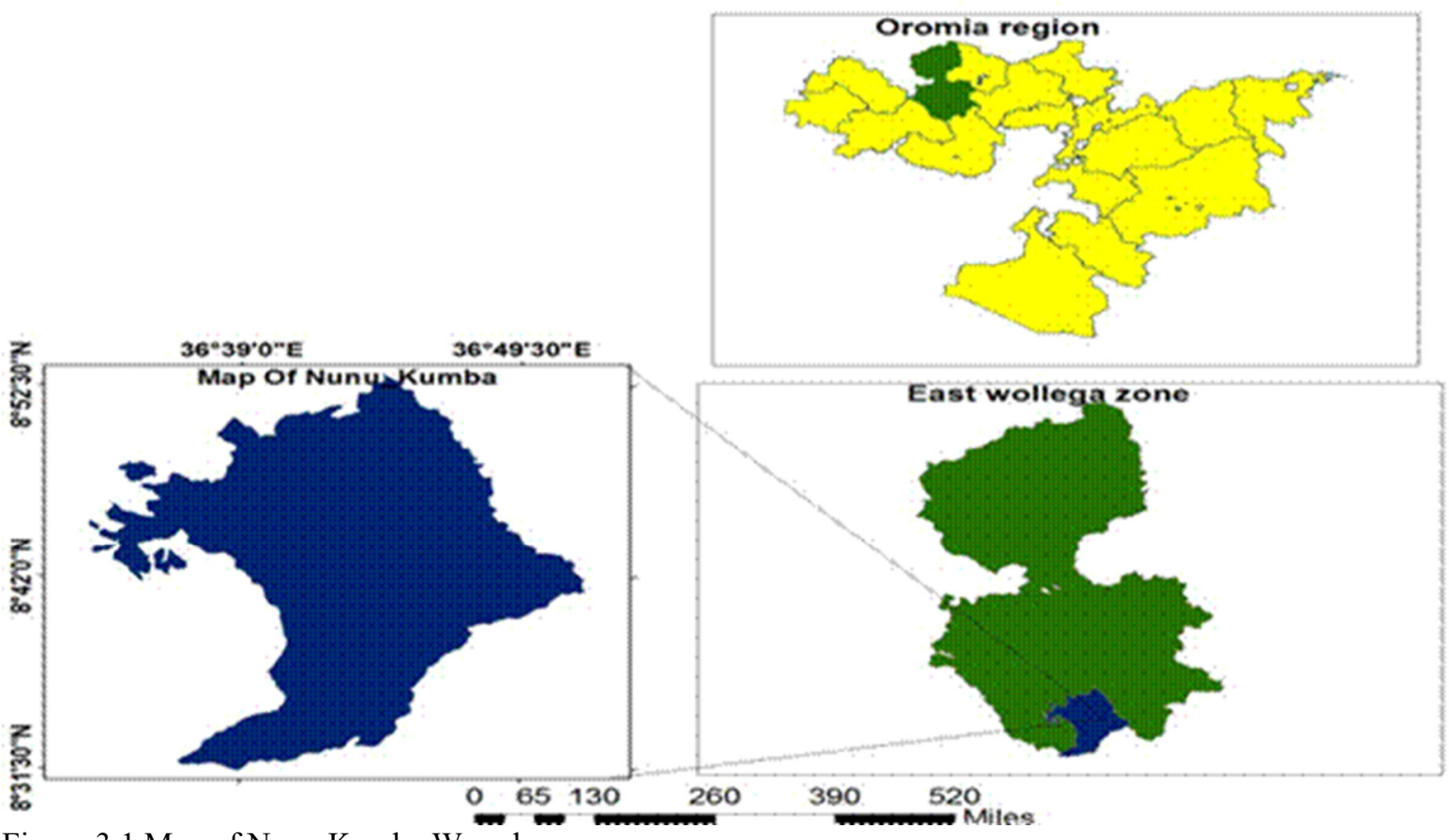

Figure 3.1 Map of Nunu Kumba Woreda

\subsection{Sample size and sampling technique}

Nunu Kumba woreda is purposively selected for this research because of the prevalence of maize producers in the area. A multi-stage sampling procedure was applied to the population of maize farmers from the area under study. In the first stage, four kebeles of maize farming are purposively selected based on the intensity of maize production in the study area. In the second stage, a 330 sample size of maize farmers were selected from four kebeles based on the formula developed by Yamane (1967). After that, the number of respondents taken from each kebeles by proportionate stratification, and the sample size of each kebeles (stratum) is proportionate to the population size of the stratum.

For this study, primary data was used. The primary data on socio-economic variables such as demographic characteristics, extension services, credit access, amount and cost of labour, oxen power used, the amount and cost of inputs used such as seed, planting fertilizer (DAP), and top dressing fertilizer (UREA), as well as the number of outputs obtained, was collected using a structured questionnaire and interview.

\subsection{Model Specification: Approaches to Efficiency Analysis}

There are two approaches to efficiency analysis which is econometric (parametric) which was used by Battese (1989), and non-parametric approach, which used by Sengupta (1989). A non-parametric method like Data Envelopment Analysis (DEA) and a parametric method like Stochastic Frontier Analysis (SFA) are two common techniques used for estimating production efficiency or inefficiency. However, SFA is applied mostly in efficiency estimation in preference to DEA because of the former has the ability to deal with stochastic noise and amenable to statistical testing of hypotheses (Coelli et al., 2005). According to Coelli et al. (1998), the stochastic frontier is considered more appropriate than DEA in agricultural applications especially in developing countries where the data is likely to be influenced by measurement errors and the effects of shocks (weather conditions, diseases, etc). 
As noted by Rathnayake and Amarathunge (nd) The stochastic frontier approach is one of the parametric approaches used to measure farm efficiency and enables to distinguish inefficiency from deviations that are caused by factors beyond the control of farmers (noise). But in DEA the method there is no functional form imposed on the production frontier and there are no assumptions made on the error term. It combines noise and inefficiency together and calls the combination inefficiency.

According to Catherine and Jeffrey (2013) stated, Cobb-Douglas function is preferable to trans log function. Cobb Douglas production has the advantage of being self-dual, a computational advantage in estimating efficiency scores and interpretation of elasticity of inputs as well as its less vulnerability to multicollinearity problem which included in trans log function. As a result, Cobb Douglas stochastic production function was applied in this study.

\subsubsection{Model specification for Allocative Efficiency}

In this study, Cobb-Douglas production function was used in measuring the allocative efficiency index of maize farmers. Maize production is a dependent variable which depends on the explanatory variables such as human labour, fertilizers applied (DAP and UREA), oxen power used, amount of seed planted and size of land allocated for maize production. Therefore, the allocative efficiency index was estimated following physical production relationships derived from the Cobb-Douglas production function. Thus, the specific model estimated is given by

$$
Y=\beta_{0} X_{1}^{\beta 1} X_{2}^{\beta 2} X_{3}^{\beta 3} X_{4}^{\beta 4} X_{5}^{\beta 5} X_{6}^{\beta 6} U_{i}
$$

Where: $Y$ is total quantity of maize produced per hectare $(\mathrm{kg}) ; X 1$ is the amount of seed planted $(\mathrm{kg}) ; X 2$ is the amount of DAP applied; $X 3$ is amount of UREA applied in maize by a household; land allocated to maize production (ha) by a given household; $X 5$ is human labour used by a given household in maize production (person days); $X_{6}$ is oxen power used for maize production; $\beta_{0}$ is constant and $U_{i}$ is error term. In order to make this function suitable to estimate by using the Ordinary Least Squares method, the function was linearized using logarithm and gave the following regression specification:

$$
\operatorname{Ln} Y=\operatorname{Ln} \beta_{0}+\sum_{i=1}^{6} \beta_{i} \operatorname{Ln} X i+U i
$$

Where $\beta_{0}$ and $\beta \mathrm{i}$ are parameters to be estimated. According to Chukwuji (2006), allocative efficiency analysis is done by estimating a Cobb-Douglas production function using OLS. It is followed by computing the value of the marginal product (VMPi) for each factor of production, which then is compared with the marginal input cost (MICi). Results from equation (4) above was provided beta estimates ( $\beta \mathrm{i})$

$\frac{\partial \ln y}{\partial \ln x}=\frac{\frac{1}{y} * \partial y}{\frac{1}{x} * \partial x}=\frac{\partial y}{\partial x} * \frac{x}{y}=\beta_{i}$

After the coefficient $\beta$ was estimated, the marginal product of the $\mathrm{i}^{\text {th }}$ factor $\mathrm{X}$ was calculated as:

$M P_{i}=\frac{\partial y}{\partial x i}=\beta_{i} \frac{y}{x i}$

$A P=\frac{y}{x i}$

Where:

- $\quad y$ is the geometrical mean of maize output

- $\quad x \mathrm{i}$ is the geometrical mean of input $i$ and

- $\quad \beta_{\mathrm{i}}$ will be the OLS estimated coefficient of input $i$

Since geometric mean is used to multiply several quantities of input together to produce a product (combine data values with a product instead of a sum as arithmetic mean), it's preferred to arithmetic and harmonic mean. The value of marginal product of input $I(\mathrm{VMPi})$ was obtained by multiplying marginal physical product (MPi ) by the price of output $(P y)$. Thus,

$$
V M P i=M P_{i} * P_{y}
$$

Finally, allocative efficiency was calculated as follow:

$$
A E=\frac{V M P i}{P i}
$$

Where: $\mathrm{Pi}=$ Marginal cost of the $\mathrm{i}^{\text {th }}$ input (unit price of input).

According to Grazhdaninova and Lerman (2004), allocative efficiency is determined by comparing the value of marginal product of input $I(\mathrm{VMPi})$ with the marginal factor cost $\left(\mathrm{MFC}_{\mathrm{i}}\right)$. Since farmers are price takers in the input market, the marginal cost of input $\mathrm{i}$ approximates the price of the factor $\mathrm{i}, \mathrm{Px}_{\mathrm{i}}$. Chavas et al. (2005) stated that, ifVMPi $>\mathrm{P}_{\mathrm{xi}}$, the input is under used and farm profit can be raised by increasing the use of this input. Conversely, ifVMPi $<\mathrm{P}_{\mathrm{xi}}$, the input is overused and to raise farm profits its use should be reduced. The point of allocative efficiency (maximum profit) is reached when $\mathrm{VMPi}=\mathrm{P}_{\mathrm{xi}}$.

\section{Stochastic frontier mode}

In this study, Cobb-Douglas production stochastic frontier which independently proposed by Aigner et al. (1977) and Meeusen and Van den Broeck (1977) was assumed to be appropriate model for the analysis of technical 
efficiency of the maize farmers. The basic advantage of the model is that it enables us to simultaneously estimate the farmers' productivity and determinants of technical efficiency (Battese and Coelli, 1992). The stochastic production function is defined as:

$$
Y=(X \beta) \exp ^{\varepsilon}
$$

$\mathrm{Y}$ is maize output $(\mathrm{kg} / \mathrm{ha})$; $\mathrm{X}$ is Vector of input quantities; $\beta$ is Vector of unknown parameters; and $\varepsilon$ is stochastic disturbance/error term consists of $\mathrm{U}$ and $\mathrm{V}$.

Based on the factors of production, the Cobb-Douglas stochastic production frontier was specified as follows:

$$
Y=\beta_{0} X_{1}^{\beta 1} X_{2}^{\beta 2} X_{3}^{\beta 3} X_{4}^{\beta 4} X_{5}^{\beta 5} X_{6}^{\beta 6} \varepsilon
$$

From this equation, the linear form of this production function was expressed as follow:

$$
L n Y=\operatorname{Ln} \beta_{0}+\sum_{\mathrm{i}=1}^{7} \beta_{i} \operatorname{Ln} X i+\mathrm{v}_{\mathrm{i}}-\mathrm{u}_{\mathrm{i}}
$$

Where: $Y$ is total quantity of maize produced per hectare $(\mathrm{kg}) ; X 1$ is the amount of seed planted $(\mathrm{kg}) ; X 2$ is the amount of DAP applied; $X 3$ is amount of UREA applied in maize by a household; land allocated to maize production (ha) by a given household; $X 5$ is human labour used by a given household in maize production (person days); $X_{6}$ is oxen power used for maize production; $\beta_{0}$ is constant; and $v i$ is the measurement errors in input use and/or yield. $u_{i}$ is also a non-negative truncated half normal, $N\left(0, \sigma_{u}^{2}\right)$ random variable associated with farmspecific factors, and technical inefficiency of the farm and ranges between zero and one. It measures the shortfall in output from its maximum value given by the stochastic frontier. A truncated distribution is a conditional distribution resulting when the domain of the parent distribution is restricted to a smaller region. As a result, truncated normal distribution was used in this study, due to the efficiency score is ranged between 0 and 1 . Technical efficiency was estimated by maximum likelihood method and efficiency levels were predicted from the stochastic frontier production function estimation. Therefore, the log likelihood for the normal-truncated normal model was specified as follow:

$$
\log L_{i}=-\frac{1}{2} \log 2 \pi-\log \sigma-\log \Phi\left(\alpha \sqrt{1+\lambda^{2}}\right)+\log \Phi\left(\alpha-\frac{\varepsilon_{i} \lambda}{\sigma}\right)-\frac{1}{2}\left(\frac{\varepsilon_{i}}{\sigma+\sigma \lambda}\right)^{2}
$$

- Where: $\Phi\left(\right.$.) is cumulative density function; $\varepsilon_{i}=y_{i}-X_{i} \beta_{i} \lambda ; \lambda=\frac{\sigma_{u}}{\sigma_{v}} ; \sigma^{2}=\sigma_{u}^{2}+\sigma_{v}^{2} ; \gamma=\frac{\sigma^{2}}{\sigma_{v}^{2}} ; \sigma=$ $\sqrt{\left(\sigma_{u}^{2}+\sigma_{v}^{2}\right)^{2}} ;$ and $\alpha=\mu / \delta \sigma$

Economic efficiency was determined from the estimation of system equations composed of a production function and of the order conditions of the production cost minimization which developed by Schmidt and Lovell (1979). It was measured using Cobb-Douglas stochastic frontier cost function for maize production by using the maximum likelihood method. For a given level of production, the economic efficiency is measured by the ratio of minimum cost to the observed cost.

$$
E E=\frac{\left(P_{i} X_{i}^{*}\right)}{\left(P_{i} X_{i}\right)}
$$

Its Cobb Douglas frontier dual cost function with double log form can be written as follow:

$$
L n C_{i}=\delta_{0}+\delta_{1} \ln \left(Y_{i}\right)+\sum_{i=2}^{5} \delta_{i} \ln W_{i}+v_{i}+u_{i}
$$

Where: $C_{i}$ is cost of production of the $i^{\text {th }}$ farm (ETB); $\mathrm{Y}_{\mathrm{i}}$ is output of the $i^{\text {th }}$ farm $(\mathrm{kg})$; $\mathrm{W}_{1}$ is wage or price of the $i^{\text {th }}$ farm input per unit of measurement; and $\delta_{0}=$ Constant.

Since economic efficiency is the product of allocative and technical efficiency, economic efficiency and technical efficiency is the basis for measuring farm specific allocative efficiency (i.e., $A E=E E / T E$ ). The allocative efficiency obtained was regressed on socio-economic and institutional factors by using Tobit model as specified below:

$$
\begin{gathered}
Y^{*}=\alpha_{0}+\alpha_{1} Z_{1}+\alpha_{2} Z_{2}+\alpha_{3} Z_{3}+\alpha_{4} Z_{4}+\alpha_{5} Z_{5}+\alpha_{6} Z_{6}+\alpha_{7} Z_{7}+\alpha_{8} Z_{8}+\alpha_{9} Z_{9}+\alpha_{10} Z_{10}+\alpha_{11} Z_{11} \\
+\alpha_{12} Z_{12} \ldots \ldots \ldots \ldots \ldots \ldots \ldots \ldots \ldots \ldots \ldots \ldots \ldots \ldots \ldots \ldots \ldots \ldots \ldots \ldots \ldots \ldots \ldots \ldots \ldots \ldots \ldots \ldots \ldots \ldots \ldots \ldots \ldots \ldots \ldots \ldots \ldots \ldots \ldots \ldots \ldots
\end{gathered}
$$

Where $Z_{1}$ is Age in years; $Z_{2}$ is educational level in years; $Z_{3}$ is farming experience in years; $Z_{4}$ is family income in birr; $Z_{5}$ is access to extension services ( $1=$ access, 0 otherwise); $Z_{6}$ is gender of respondent ( $1=$ male, 0 female); $Z_{7}$ is credit utilization ( $1=$ utilize, 0 otherwise); $Z_{8}$ is the household size in numbers; $Z_{9}$ is total farm size of household; $Z_{10}$ is off-farm income ( $1=$ yes, 0 otherwise); $Z_{11}$ is livestock holding ( $1=$ holding, 0 otherwise); and $Z_{12}$ is distance from the near market. 


\section{Result and Discussion}

\section{Estimation of allocative efficiency}

The farmers' allocative efficiency estimates of their production resources were presented in table 4.1 To enable this estimation, marginal physical product, value of marginal product, and marginal factor costs (unit price of input factors) were determined.

The results of allocative (resource use efficiency) are presented based on the following criteria; when $\mathrm{AE}=1$, resources are optimally utilized, when $\mathrm{AE}<1$, resources are over utilized and when $\mathrm{AE}>1$, resources are underutilized.

The result presents that the efficiency indicator $(A E=21.31)$ of seed took a positive sign which shows that planted seeds were being underutilized. To use seed efficiently, farmers need to increase the amount of seed which has high quality and disease resistance traits.

The efficiency indicator ( $\mathrm{AE}=4.15$ ) of planting fertilizer (DAP) took a positive sign which portrayed that planting fertilizer is underutilized. A farmers is said to be allocative efficient at the optimum, they need to increase the use of planting fertilizer from the current quantity they are using. That means when they increase the amount of planting fertilizer from the current level, they become efficient maize producer. This implies that planting fertilizer is very important and has a significant effect on maize output.

The efficiency indicator of land size allocated for maize production is less than one (AE $=0.94)$, which suggests that lands were over utilized. The value of the marginal product of land was less than its costs. Accordingly, land was not optimally used and farmers should reduce the expenditure on rented land to obtain optimum utilization of land.

The efficiency indicator of top dressing fertilizer (TDF) is -2.84 , which showed that maize farmers were not only grossly inefficient in the use of top dressing fertilizer but also the marginal value of overusing it was negative. This requires using the required amounts of top dressing fertilizer to become an efficient or optimal point of using it. This reduction should be done only up to the level where AE equals to one and positive. This implies that miss utilization of fertilizers affects productivity negatively.

The efficiency indicator for labour $(\mathrm{AE}=1.54)$, shows that maize farmers are underutilized the labour resource. To obtain the optimum value of labour use, it is required to increase the labour use per man-day. This finding also consistent with the findings of Nzomoi (2006) who identified that the amount of labour force employed by a producer significantly influences the amount of average output and profitability. Thus increased family labour to an optimal level of one man hour per day not only leads to improved maize output and profitability but also reduces the problem of marginal product of labour is less than the average value of goods and services consumed by the family member.

The result also showed that return to the scale of this production is 0.992 which shows maize production in the study area follows decreasing return to scale. It implies that output increases less than proportionately as all inputs increase proportionately. That means output was increased by less than increased (doubled) input, which arises from inefficiently allocating resource.

Table 4. 1 Allocative Efficiency Index

\begin{tabular}{lrrrrrrr}
\hline Variable & Coefficient & APi & MPi & Py & VMPi & Pxi & AE \\
\hline Seed & 0.542 & 169.75 & 92 & 5 & 460.59 & 21.6 & 21.31 \\
DAP & 0.251 & 42.445 & 10.67 & 5 & 53.33 & 12.84 & 4.15 \\
Land & 0.137 & 3313.09 & 452.87 & 5 & 2264.33 & 2400 & 0.94 \\
UREA & -0.179 & 42.089 & -7.52 & 5 & -37.59 & 13.26 & -2.84 \\
Labour & 0.24 & 25.607 & 6.15 & 5 & 30.74 & 20 & 1.54 \\
Return to scale & 0.992 & & & & & &
\end{tabular}

Source: Field survey, 2019 GC.

\section{Determinants of Allocative Efficiency}

The mean of allocative efficiency score was $79.49 \%$ which indicated that on average maize producer farmers in the study area used resource $79.49 \%$ efficiently and $20.51 \%$ of inputs were used below the optimal allocative efficiency level. There is a chance to increase the efficiency of maize producers by reallocating resources in cost minimizing way. The result suggests that the farmer with an average of allocative efficiency would enjoy a cost saving of $15.71 \%$ (i.e. $1-0.7949 / 0.943$ ) to attain the level of the most allocatively efficient household. The most allocatively inefficient farmer would have an efficiency gain of $49.95 \%$ (i.e. 1-(.0.472/0.943)) to attain the level of the most efficient farmer.

Table 4.2 presents the results of censored Tobit model regression of selected socio-economic and institutional support factors against farm allocative efficiency scores. Among the selected variables, experience, livestock holding, and extension visit was not significant, while the others were significant determinants of allocative efficiency. 
As the result presented that allocative efficiency was positively and significantly influenced by education at $5 \%$ level. It indicates that allocative efficiency requires better knowledge and skills, which shows an educated farmer have better capacity in the optimal allocation of inputs than uneducated farmer. That means skilled farmers to have better skills of managing farm operations and understand new technologies that increase their production. This result is in line with the finding of Musa (2015), Kebede (2001), Saulos (2015) and Amaza and Olayemi (2000), stated education is an important factor in enhancing efficiencies of maize producer in the study; since educated farmers are access with improved and new technology which enhances productivity.

The result showed that farms size positively and significantly affect allocative efficiency at 5\% level. It indicates that an increase in the farm size by a unit would increase the farm allocative efficiency by $2.8 \%$. The result is consistent with the finding of Musa (2015) and Saulos (2015), found that a unit change in farm size would result a positive change in the probability of a farmer being allocatively efficient. As well as Bravo-Ureta and Pinheiro (1997) of Dominican Republic and Wadud (2003) of Bangladesh found that larger farmers tend to be more efficient in allocating inputs than small.

The result presented that age of the household have negative coefficient, and significantly affected allocative efficiency at $10 \%$ level. The result showing that one year increase in the farmer's age reduce the level of allocative efficiency by $1.4 \%$. As the age of farmer's become increase and older, their ability to allocate resource appropriately would decrease. But it doesn't mean as the age of farmers in working age group increase, it reduces their ability of allocating resource efficiently. Because as their age was increased their ability of allocating farm input also increase until they become out of working age group and tired, and then decrease. Sex of household head was also found to have a negative and significant effect on allocative efficiency at $10 \%$. It implies that maleheaded household less allocatively efficient than a female-headed household.

The experience of a household was affected allocative efficiency positively but not significant. It implies that a one year increase in the farmer's experience would increase allocative efficiency by $1.5 \%$. That means more experienced farmers are appropriately allocated resource than less or inexperienced farmers. This result was in line with the finding of Nwachukwu and Onyenweaku (2009). Arrow (1972) stated in the literature of "economic implication of learning by doing" that management experience can guide to gain efficiency through better organization and knowledge of the results of experimenting with alternative production techniques.

The coefficient of livestock holding was positive and affected allocative efficiency positively. It indicates that a farmer who has livestock more allocative efficient by $2.9 \%$ than who doesn't have a livestock. Livestock has many contributions to farm activity because by selling them, farmers could purchase enough farm inputs. It's in line with the finding of Musa (2015), Kifle (2017) and Saulos, (2015), were found that livestock holding positively affect the allocative efficiency of farmers'. However, it is inconsistent with the finding of Bealu (2013).

Participation of households in off-farm income negatively and significantly affected allocative efficiency at $10 \%$ level. This indicates that a farmer who participates in off-farm income at farm season less allocatively efficient than who doesn't participate. The participations of households in non-farm activity was reallocate time away from farm and so less attend allocative efficiency enhanced activities which were given by agricultural development agency. The result is consistent with the finding of Bealu (2013), Musa (2015), and Kibaara (2005). But inconsistent with the finding of Kifle (2017) stated that off farm income help to improve allocative efficiency of farmers by overcoming financial constraint. However, off-farm income affects negatively allocative efficiency since they drop farm activity and go to do none farm activity. As a result, it is better if they participate in off-farm income generating activity at none farm seasons than at regular farm season. That means farmers doing none farm income generating activity by the opportunity cost of farm season which in turn harm efficiency of farmers.

According to the result presented, household size has negative coefficient and significantly affected allocative efficiency at $5 \%$ level. This implies that large households reduce the level of allocative efficiency of farmers by reducing farm income by putting extra pressure on farm income for food, clothing and education. The result is consistent with the finding of Nwachukwu, and Onyenweaku (2009) found that larger family size endangers reduction in the magnitude of allocative efficiency.

The result also showed that distance to the market positively affected allocative efficiency and significant at $5 \%$ level. This implies that when market distance increase by $1 \mathrm{~km}$ the allocative efficiency of farmers could increase by $0.9 \%$. Since long market distance by itself restricted the frequency and interest of farmers went to the market in a week, they didn't went many times in a week than once a week or by a two week, and enforce as they expended more time and put their full attention on farm activity than try to do other activity besides at farm season which harms allocative efficiency (i.e. off-farm income). But those found nearest to the market went many times in a week and also do off-farm activity as well as share their time and attention between off farm income and farm activity. As a result, they couldn't be allocatively efficient as those found far away from the market, but the supply of input (input market) is mandatory to found nearest to farmers than other markets. Because the opportunity cost of found nearest to the market is off-farm income which negatively affect allocative efficiency of the farmer.

According to the result revealed, coefficient of credit utilization was negative and significant at $5 \%$ level. It might be due to the amount of available credit doesn't cover the cost of input; consequently, farmers bought little 
inputs and inefficiently allocate it. The result is consistent with the finding of Nwachukwu and Onyenweaku (2009) have observed a significant negative relationship between the access of credit and allocative efficiency. Their argument was that inaccessibility of credit acts as a constraint in timely purchases of inputs and engagement of farm resources and thus puts an obstacle in improving the allocative efficiency in agriculture.

Table 4. 2 Determinants of Allocative Efficiency

\begin{tabular}{lcrr}
\hline Variable & Coefficient & Standard Error & t value \\
\hline Constant & $0.972^{* * *}$ & 0.050 & 19.56 \\
Sex & $-0.038^{*}$ & 0.021 & -1.85 \\
Age & $-0.014^{*}$ & 0.008 & -1.74 \\
Family size & $-0.024^{* *}$ & 0.010 & -2.34 \\
Education & $0.021^{* *}$ & 0.008 & 2.59 \\
Experience & 0.015 & 0.011 & 1.33 \\
Family income & -0.008 & 0.007 & -1.12 \\
Off farm income & $-0.025^{*}$ & 0.014 & -1.76 \\
Livestock holding & $0.029^{*}$ & 0.016 & 1.76 \\
Farm size & $0.028^{* *}$ & 0.011 & 2.47 \\
Market distance & $0.009^{* *}$ & 0.004 & 2.21 \\
Extension access & -0.017 & 0.016 & -1.11 \\
Credit utilization & $-0.028^{*}$ & 0.015 & -1.81 \\
\hline Mean & 0.7949 & & \\
Minimum & 0.472 & & \\
Maximum & 0.943 & & \\
\hline Source: Filed survey & $0.94 *$ &
\end{tabular}

Source: Filed survey, 2019 GC. Note: *, **, and *** represents the significant at $10 \%, 5 \%$ and $1 \%$ level.

\section{Conclusion and Recommendation}

The study concluded that maize farmers in the study area were not fully allocatively efficient in their production activities that need to increase this productivity of maize significantly. Allocative efficiency was significantly affected by education, farm size, livestock holding, and market distance, off farm income, and credit utilization. Based on the finding $\mathrm{f}$ the study, it is recommended that extension service experts should focus on training of the farmers on improved production management to enable as they use the existing resources efficiently and increase the productivity of maize. The Government should give due attention for farmers training through strengthening farmers' education and farmer training centers to make farmers more efficient producers and profitable by integrating local and traditional knowledge of farmers with formal knowledge. Farmers should be advised as they didn't work off-farm income generating activity at farm season. If they face a financial constraint, they should have to use credit and credit provider should give enough credit on time. Otherwise, the government should supply fertilizer and improved seed on credit.

\section{References}

Abate, T., Shiferaw, B., Menkir, A., Wegary, D., Kebede, Y., Tesfaye, K., \& Keno, T. (2015).Factors that transformed maize productivity in Ethiopia. Food Security, 7(5), 965-981.

Aigner, D., Lovell, C. K., \& Schmidt, P. (1977). Formulation and estimation of stochastic frontier production function models. Journal of econometrics, 6(1), 21-37.

Alemayehu S, Dorosh P, Sinafikeh A. (2012). Crop production in Ethiopia: Regional Patterns and Trends Ethiopia in Food and Agriculture in Ethiopia: Progress and Policy challenges.

Arrow, K. J. (1962).The Economic Implications of Learning by Doing. Rev. Econ. Stud. 29(1962):155-73

Bagamba, F. Ruerd, R, \& Mariana, R. (2007). Determinants of banana productivity and technical efficiency in Uganda.

Battese, G. E., \& Coelli, T. J. (1992).Frontier production functions, technical efficiency and panel data: with application to paddy farmers in India. Journal of productivity analysis, 3(1-2), 153-169.

Bealu, T., Endrias, G. and Tadesse, A. (2013). Factors affecting economic efficiency in maize production: the case of boricha woreda in sidama zone, southern Ethiopia.

Bello, K. G., Musa, D., Manza, E. A. G., Idris, A. K., and Ahmed, L. A. 2018). Allocative Efficiency in Layer and Broiler Production in Sokoto State, Nigeria. International journal of innovative research and development, Vol 7 Issue 8

Bravo-Ureta, B. E., \& Pinheiro, A. E. (1997).Technical, economic, and allocative efficiency in peasant farming: evidence from the Dominican Republic. The Developing Economies, 35(1), 48-67.

Chavas, J. P., Petrie, R. and Roth, M. (2005).Farm Household Production Efficiency: Evidence from The Gambia. American Journal of Agricultural Economics 87(1): 160-179. 
Chukwuji, C. O., Inoni, O. E., \& Oyaide, W. J. (2006).A quantitative determination of allocative efficiency in broiler production in Delta State, Nigeria. Agriculture Conspectus Scientificus, 71(1), 21-26.

CSA. (2014). Agricultural Sample Survey 2013/2014 (2006 E.C.): Volume I - Report on Area and Production of Major Crops (Private Peasant Holdings, Meher Season). Statistical Bulletin. Addis Ababa: Central Statistical Agency.

Fan, S. (1999). Technological Change, Technical and Allocative Efficiency in Chinese Agriculture: The Case of Rice Production. In in China, ”International Food Policy Research Institute, EPTD Discussion Paper.

Forsund, F. R., Lovell, C. K., \& Schmidt, P. (1980). A survey of frontier production functions and of their relationship to efficiency measurement. Journal of econometrics, 13(1), 5-25.

Garvelink, W. J., Wedding, K., \& Hanson, S. (2012). Smallholder agriculture: A critical factor in poverty reduction and food security in Africa. Center for Strategic and International Studies.

Gollin, D. (2009). Agriculture as an Engine of Growth and Poverty Reduction.

Inoni, O. E. (2007). Allocative efficiency in pond fish production in Delta State, Nigeria: A production function approach. Agriculturatropicaetsubtropica, 40(4), 127-134.

Jon P. (2007). The Adoption and Productivity of Modern Agricultural Technologies in the Ethiopian Highlands: A Cross-Sectional Analysis of Maize Production in the West Gojam Zone, University of Sussex.

Kebede, T. A. (2001). Farm Household Technical Efficiency, A Stochastic Frontier Analysis. A Study of Rice Producers in Mardi Watershed in the Western Region of Nepal. A Master's thesis submitted in Department of Economics and Social Science, Agricultural University of Norway.

Kibaara, B.W. (2005). Technical efficiency in Kenyans' maize production: An application of the stochastic frontier approach. Colorado State University

Kifle, D., Moti, J. and Birhanu, L. (2017). Economic Efficiency of Smallholder Farmers in Maize Production in Bako Tibe District, Ethiopia. ISSN 2224-607X (Paper) ISSN 2225-0565 (Online)

Meeusen, W., \& van Den Broeck, J. (1977). Efficiency estimation from Cobb-Douglas production functions with composed error. International economic review, 435-444.

Minten, B., Stifel, D., \&Tamru, S. (2012). Structural transformation in Ethiopia: Evidence from cereal markets. IFPRI-ESSP II Working Paper 39

MoA. (2014). Manual for Maize Technology Utilization (Amharic Version), Addis Ababa, Ethiopia

Musa, H. A., Lemma, Z., \& Endrias, G. (2015). Measuring technical, economic and allocative efficiency of maize production in subsistence farming: Evidence from the Central Rift Valley of Ethiopia.APSTRACT: Applied Studies in Agribusiness and Commerce, 9(1033-2016-84288), 63.

NSO.(2014).Assessment of Ethiopia with a focus on agricultural issues.https://g4aw.spaceoffice.nl/files/countries/Ethiopia/FINAL\%20G4AW\%20Quickscan\%20Ethiopia.p df

Nwachukwu, I.N. and Onyenweaku, C.E. (2009). Allocative efficiency among Fadama fluted pumkin farmers in Imo State, Nigeria. Int. J. Agric. Rural Dev., 11: 129-136.

Okoye, B. C., Onyenweaku, C. E., \& Asumugha, G. N. (2006). Allocative efficiency of small-holder cocoyam farmers in Anambra State, Nigeria. http://mpra.ub.unimuenchen.de/17362/

Philiphos, M. (2014). Technical and Allocative Efficiency of Maize Production in MeskanWoreda of Gurage Zone

Saulos J. (2015). Survey on Technical, allocative, and economic efficiency of maize production using the parametric stochastic frontier production function. African journal of agricultural economics and rural development. pp. 27-245.

Schmidt, P., Aigner, D.J., and Lovell C.A.K., (1977). Formulation and estimation of stochastic frontier function models, J. Econ., 6(1): 21-37.

Tijani, A.A. (2006). Analysis of the technical efficiency of rice farms in Ijesha land of Osun state, Nigeria. Journal of Agriculture Economics

Ugwumba, C.O.A. (2010). Allocative Efficiency of 'Egusi’ Melon (Colocynthiscitrulluslanatus) Production Inputs in Owerri West Local Government Area of Imo State, Nigeria. Journal of Agricultural Science, 1: 95-100.

Wadud, A. (2003). Technical, allocative and economic efficiency of farms in Bangladesh: A stochastic frontier and DEA approach. J. Dev. Areas, 37: 109-126.

Xinshen, D., Alemayehu, Seyoum, T., Bingxin, Y., and Alejandro, N. P. (2010). Economic Importance of Agriculture for Sustainable Development and Poverty Reduction: the Case Study of Ethiopia, International Food Policy Research Institute (IFPRI).

Yamane, T. I. (1967). Statistics: An Introductory Analysis, 2nd Edition. Harper and Row, New York. 